\title{
Health Education with a Leaflet and Demonstration to Improve the Implementation of Washing the Hands of Nurse
}

\author{
$1^{\text {st }}$ Sri Handayani \\ Nursing Department \\ STIKES Muhammadiyah Klaten \\ J1 Ir Soekarno Km 1 Buntalan 57419, \\ Klaten, Indonesia \\ handayani@stikesmukla.ac.id \\ $4^{\text {th }}$ Hartini \\ Nursing Department \\ STIKES Muhammadiyah Klaten \\ J1 Ir Soekarno Km 1 Buntalan \\ 57419, Klaten, Indonesia
}

\author{
$2^{\text {nd }}$ Chori Elsera \\ Nursing Department \\ STIKES Muhammadiyah Klaten \\ J1 Ir Soekarno Km 1 Buntalan \\ 57419, Klaten, Indonesia
}

\author{
$3^{\text {rd }} \mathrm{N}$ W Agustina \\ Nursing Department \\ STIKES Muhammadiyah Klaten \\ J1 Ir Soekarno Km 1 Buntalan \\ 57419, Klaten, Indonesia
}

\begin{abstract}
Hospitals are complex medical service units, as well as places to interact between patients, health workers, visitors and patient nurses. The existence of this interaction risks causing nosocomial infections. The practice of hand washing must be applied by everyone in the hospital environment to prevent the occurrence of nosocomial infections. The purpose of this study was to determine the effect of health education with leaflets and demonstrations on compliance with the implementation of hand washing on patient caregivers. The study design used quasiexperimental design with non-equivalent control group design. The experimental group was given health education with leaflets and demonstrations. Compliance with the implementation of hand washing was measured twice, namely before and after being given health education by means of observation. The study sample was 30 subjects. The sampling technique uses purposive sampling. The results showed that in the experimental group there was an increase in adherence to the implementation of hand washing in the patient's guardian at $60 \%$, while in the control group it was $13.3 \%$. The results of the chi square test obtained pvalue $=$ $0.035<\alpha(0.05)$ which means that health education using leaflets and demonstrations can improve compliance with the implementation of hand washing of patient caregivers.
\end{abstract}

Keywords-Health Education, Hand Washing, Patient Caregivers?

\section{INTRODUCTION}

Infectious diseases related to health services is one of the health problems in various countries in the world, including Indonesia. In principle, infectious diseases can be prevented if health service facilities / hospitals consistently implement Infection Prevention and Control programs (Ministry of Health Republic of Indonesia, 2017). One of the infection prevention and control programs is the implementation of hand washing. Hand washing is an inexpensive and important routine to prevent the transmission of microorganisms in order to control transmission of infection (James, 2008). The implementation of hand washing must be applied to all elements of the hospital ranging from doctors, nurses, administrative staff, patients, hospital visitors and patient caregivers. However, not all elements of the hospital carry out hand washing practices.

The study (Othman \& Jonker, 2018) concluded that the average observed level of hand hygiene compliance was $45.7 \%$ (95\% CI 37.1-54.3). Nurses have better compliance than doctors. The staff observed seemed more concerned about hand hygiene after contact with patients than before contact. Research (Bucher, Donovan, OhmanStrickland, \& McCoy, 2015) Overall, reported hand hygiene practices were poor among pre-hospital providers in all clinical situations. Researchers (Sanjeev, Dwidmuthe, \& Dwidmuthe, 2016) concluded that the awareness and knowledge of preoperative surgical hand scrubbing was moderate in doctors, but unfortunately poor in HCWs. Research (Fauzia, Ansyori, Hariyanto, Pidie, \& Medan, 2014) concludes that nurses' hand hygiene behavior is in accordance with hospital operating procedures standards by $36 \%$.

Hand washing is not only applied to hospital medical personnel, but must also be applied to the patient's caregivers or hospital visitors. Patient'S caregivers are one of the groups most at risk of infection, because they interact with patients the most. Infection can be transmitted from the patient to the health worker and from the patient to the Patient'S caregivers or the patient's family. Research (Canti, Husodo, \& Mustofa, 2016) on the Patient'S caregivers at Dr Adyatma Tugurejo Hospital Semarang found $28.6 \%$ of respondents did not practice hand hygiene according to procedures. The results of the study (Erica \& Simanjuntak, 2019) found the average number of hand bacteria of visitors to ICCU was 73.40 cells / cm2, this condition could be an indication of infection transmission.

The implementation of hand washing on the patient caregivers is influenced by many factors, one of which is knowledge. Knowledge is a very important domain in shaping one's behavior. The results of the study (Mumpuningtias, Aliftitah, \& Illiyini, 2017) concluded 
that $60 \%$ of patients' families have less knowledge about handrubs. The study (Fajriyah, 2015) concluded that $17.9 \%$ of patient caregivers had less knowledge about hand washing antiseptic lotions. The results of the study (Canti et al., 2016) concluded that there was a relationship between respondents' knowledge and the practice of hand hygiene on the patient caregivers.

Health education is very important to provide a basic understanding of hand washing for the patient caregivers. In line with the research (Iskandar \& Yanto, 2018), there was an influence of health education on the 6 step 5 moment hand washing behavior in patients' families. Health education can achieve maximum results if the methods used are in accordance with the objectives. The use of a combination of methods and media will greatly assist in the process of delivering information to the target.

Based on the description above, it is necessary to conduct research on the effect of handwashing health education using leaflets and demonstrations on the compliance of the implementation of hand washing in patient caregivers.

\section{METHODS}

We used a quasi-experiment with non-equivalent control group design in this study. The research sample of 30 people who are inpatients. The samples were chosen by using a purposive sampling method. Sample criteria are people who wait for patients for 2 consecutive days.

This study uses a questionnaire method to assess the knowledge of hand washing and observation methods to assess the implementation of patient caregivers hand washing. Hand washing can be done using a handrub, handwash or tap running water. Observation was carried out 3 times a day. Then on the following day the respondents of the experimental group were given a demonstration of health education on how to properly wash their hands and also given leaflets. While the control group respondents were only given leaflets. One day later the respondent was observed again to assess the implementation of hand washing. The results of the assessment of the implementation of hand washing before and after being given health education were analyzed using the Mc Nemar test. While the results of the assessment of the implementation of hand washing in the experimental group and the control group were analyzed using the chi-square test.

\section{RESUlTS}

Respondents' knowledge about hand washing both the experimental group and the control group before being given health education was lacking. The results of the assessment of knowledge about hand washing are presented in table 1 below:
TABLE 1. RESPONDENTS KNOWLEDGE ABOUT

\begin{tabular}{|c|c|c|c|c|c|}
\hline \multirow{2}{*}{ Group } & \multirow{2}{*}{ Knowledge } & \multicolumn{2}{|c|}{ Pre } & \multicolumn{2}{|c|}{ Post } \\
\hline & & $\mathrm{f}$ & $\%$ & $\mathrm{f}$ & $\%$ \\
\hline \multirow[t]{3}{*}{ Eksperimen } & Well & 0 & 0 & 0 & 0 \\
\hline & Enough & 5 & 33,3 & 12 & 80 \\
\hline & Less & 10 & 66,7 & 3 & 20 \\
\hline \multirow[t]{3}{*}{ Kontrol } & Well & 0 & 0 & 0 & 0 \\
\hline & Enough & 4 & 26,7 & 14 & 93,3 \\
\hline & Less & 11 & 73,3 & 1 & 6,7 \\
\hline
\end{tabular}

Mc Nemar test results concluded that there were differences in the implementation of hand washing before and after being given a combination of health education using leaflets and demonstrations, but there were no differences in the implementation of hand washing before and after being given leaflets. The analysis results are presented in table 2 .

TABLE 2. WASHING HANDS BEFORE AND AFTER THE EXPERIMENT

\begin{tabular}{lcccc}
\hline \multirow{2}{*}{ Group } & \multirow{2}{*}{ Pre } & \multicolumn{2}{c}{ Post } & \multirow{2}{*}{ Pvalue } \\
\cline { 3 - 4 } & & Obedient & Not obey & \\
\hline Eksperim & Obedient & 5 & 0 & 0,004 \\
en & Not obey & 9 & 2 & \\
\hline Kontrol & Obedient & 6 & 0 & 0,5 \\
& Not obey & 2 & 7 & \\
\hline
\end{tabular}

Chi-square test results concluded there is an influence of health education using leaflets and demonstrations on the implementation of hand washing on the patient caregivers. The analysis results are presented in table 3

TABLE 3. HANDWASHING OF THE EXPERIMENTAL AND CONTROL GROUPS

\begin{tabular}{cccccccc}
\hline \multirow{3}{*}{ Group } & \multicolumn{3}{c}{ Handwashing } & & Total & \multirow{2}{*}{ Pvalue } \\
\cline { 2 - 5 } & \multicolumn{2}{c}{ Obedient } & \multicolumn{2}{c}{ Not obey } & & & \\
\cline { 2 - 6 } & $\mathrm{f}$ & $\%$ & $\mathrm{~F}$ & $\%$ & $\mathrm{f}$ & $\boldsymbol{\%}$ & \\
\hline Eksperimen & 14 & 93.3 & 1 & 6.7 & 15 & 100 & 0.035 \\
Kontrol & 8 & 53.3 & 7 & 46,7 & 15 & 100 & \\
\hline Total & 22 & 73.3 & 8 & 26.7 & 30 & 100 & \\
\hline
\end{tabular}

\section{DISCUSSIONS}

Nosocomial infections contribute greatly to the high mortality rate of patients. Infection Prevention and Control is an effort to ensure protection of everyone against the possibility of contracting infection from public sources and while receiving health services at various health facilities. WHO launched a patient safety program to reduce the number of nosocomial infections (World Health Organization, 2002). WHO also created a Global patient safety safety program with clean care is safe care which is a strategy to promote handwashing in health workers (WHO, 2011). Transmission of nosocomial infections not only occurs in patients and medical staff, but also at high risk for hospital visitors and patient caregivers.

One effective way to cut off transmission of infection is by washing hands. Hand washing is an inexpensive and easy activity but is very effective in preventing the transmission of microorganisme (James, 2008). The fact is that not everyone is aware of the 
importance of washing hands. The results of the study found that before being given health education a patient caregivers in the experimental group was $66.7 \%$ disobedient to wash hands, whereas in the control group as much as $60 \%$. The hand is a part of the body that is in contact with many objects and other people, so it is most vulnerable to be the intermediary of microorganisme causing disease. These results are in line with research (Erica \& Simanjuntak, 2019) that the bacterial count before the hand washing was 73.40 cells $/ \mathrm{cm} 2$, and the mean of bacterial counts after the hand washing was 12.50 cells / cm2. The Staphylococcus sapropytuicus, Bacillus sp. and Staphylococcus epidermis were also found at the visitors hands. One way to improve hand washing behavior is by providing health educationn.

Health education is a conscious effort to bring about changes in the behavior of healthy living both the community and social environment. Health education can achieve maximum results if the methods used are in accordance with the objectives. The use of a combination of methods and media is very helpful in the process of delivering information to the target. The results showed that health education using leaflets did not affect the implementation of patient caregivers hand washing. The results also found that compared to the leaflet method alone, education with leaflets and demonstrations changed the implementation of washing hands better.

Respondents given leaflets often do not read so they do not understand the contents of the leaflet. (Notoatmojo, 2003) states that leaflets are a type of extension media that is conducted in one direction only. Success rates are difficult to evaluate because participants are passive and only active educators. The results of this study are in line with the findings (Norviatin, Early, Adiguna, \& Yudha, 2017) that the provision of leaflets cannot improve knowledge, attitudes, and behavior about diarrhea in mothers who have children under five in the work area of the Majalengka Health Center. In line with research (Iskandar \& Yanto, 2018) that there is an influence of health education on the 6 step 5 moment hand washing behavior of patients' families at Roemani Muhammadiyah Hospital Semarang. Likewise, the conclusions of the study (Nuraida, Fauzie, \& Purwanto, 2015) that counseling with lecture and demonstration methods change better knowledge, attitudes and skills in washing hands using soap.

\section{CONCLUSIONS}

Based on the results of the study it can be concluded that health education with leaflets and demonstrations can be used as a method to improve the implementation of washing the hands of patient caregivers.

\section{ACKNOWLEDGMENT}

Thank you to the Chairperson of College of Health Sciences Muhammadiyah Klaten for providing the opportunity to carry out this research. Our gratitude goes also to the Director of the Cawas Klaten Islamic Surgical Special Hospital

\section{REFFERENCES}

[1] Bucher, J., Donovan, C., Ohman-Strickland, P., \& McCoy, J. (2015). Hand Washing Practices Among Emergency Medical Services Providers. Western Journal of Emergency Medicine, 16(5), 727-735. https://doi.org/10.5811/westjem.2015.7.25917

[2] Canti, P. R., Husodo, B. T., \& Mustofa, S. B. (2016). Hubungan Paparan Media Informasi Terhadap Praktik Hand Hygiene Pada Penunggu Pasien Di Instalasi Rawat Inap RSUD Dr. Adhyatma Tugurejo Kota Smarang. Jurnal Kesehatan Masyarakat Universitas Diponegoro, 4. Retrieved from https://www.neliti.com/journals/jurnal-kesehatan-masyarakatuniversitas-diponegoro

[3] Erica, S., \& Simanjuntak, S. M. (2019). The Hand Hyhiene and Bacterial Colonies Count Of ICCU, Visitors Hands: as an Indicator for Nosocomial Infection Prevention, 1(1).

[4] Fajriyah, N. N. (2015). Pengetahuan Mencuci Tangan Penunggu Pasien Menggunakan Lotion Antiseptic. In The 2nd University Research Coloquiium 2015 (pp. 557-562). Retrieved from https://jurnal.unimus.ac.id/index.php/psn12012010/article/view/ 1636/1688

[5] Fauzia, N., Ansyori, A., Hariyanto, T., Pidie, A. K., \& Medan, J. (2014). Kepatuhan Standar Prosedur Operasional Hand Hygiene pada Perawat di Ruang Rawat Inap Rumah Sakit Adherence to the Standard Operating Procedures on Hand Hygiene of Nurses in Hospital's Inpatient Unit 12 2. Jurnal Kedokteran Brawijaya, 28(1), 51121. Retrieved from https://jkb.ub.ac.id/index.php/jkb/article/view/526/405

[6] Iskandar, M. B., \& Yanto, A. (2018). Peng aruh Pendidikan Kesehatan terhadap Pelaksanaan Cuci Tangan 6 Langkah 5 Momen Keluarga Pasien di Ruang Rawat Inap RS Roemani Semarang dirawat, termasuk rumah sakit. Mencuci tangan merupakan rutinitas yang murah dan penting perkembangbiakan mikroorga. In Prosiding Seminar Nasional Mahasiswa Unimus (Vol. 1, pp. 120-128). Retrieved from http://prosiding.unimus.ac.id/index.php/mahasiswa/article/view/ $108 / 138$

[7] James, J. (2008). Prinsip-prinsip Sains untuk Keperawatan. Jakarta: Erlangga.

[8] Kemenkes RI. (2017). Pedoman Pencegahan dan Pengendalian Infeksi di Fasilitas Pelayanan Kesehatan.

[9] Mumpuningtias, E. D., Aliftitah, S., \& Illiyini. (2017). Hubungan Tingkat Pengetahuan dengan Perilaku Cuci Tangan Menggunakan Hansrub pada Keluarga Pasien di Ruang Bedah RSUD dr. H Moh. Anwar Sumenep. Jurnal Ilmiah Keperawatan, 12(2).

[10] Norviatin, Dini, Adiguna, \& Yudha, T. (2017). Pengaruh Penyuluhan dan Pemberian Leaflet terhadap Peningkatan Pengetahuan, Perilaku, dan Sikap Ibu Tentang Diare pada Balita di Puskesmas Maja Kabupaten Majalengka. Tunas Medika Jurnal Kedokteran \& Kesehatan, 3(4), 40-45. Retrieved from http://jurnal.unswagati.ac.id/index.php/tumed/article/view/287

[11] Notoatmojo, S. (2003). Pendidikan dan Perilaku Kesehatan. Jakrata: Rineka Cipta.

[12] Nuraida, C., Fauzie, M. M., \& Purwanto. (2015). Dengan Metoda Ceramah Disertai Demonstrasi Mencuci Tangan Memakai Sabun Siswa Sd Negeri Pujokusuman 1 Kota Yogyakarta. Jurnal Kesehatan Lingkungan, 7(1), 1-6.

[13] Othman, M., \& Jonker, C. (2018). Hand Hygiene Among Hospital Staff: a Survey Of Knowledge, Attitude, And Practice In a General Hospital In Syria. Jurnal Keperawatan Indonesia, 21(3), 139-149. https://doi.org/10.7454/jki.v21i3.513

[14] Sanjeev, R., Dwidmuthe, S. C., \& Dwidmuthe, K. S. (2016). The Knowledge OF Health Care Workers And Doctors Regarding Hand Scrub, 3(66), 3575-3578. https://doi.org/10.18410/jebmh/2016/767

[15] WHO. (2011). Report on the burden of endemic helath careassociated infection worldwide: clean care is safe care.

[16] World Health Organization. (2002). Prevention of hospitalacquired infections World Health Organization. 